\title{
Japanese Language, Standard Language, National Language: Rethinking Language and Nation
}

\author{
Luka CULIBERG*
}

\begin{abstract}
The paper examines the relationship between language and nation through the historical process by which the modern Japanese language came to exist and proposes a tentative answer as to what this says about the nature of phenomena such as language and nation themselves. The paper suggests that if language is understood as an actually existing natural and definable object, it must indeed be claimed that the Japanese language is no more than a hundred years old.
\end{abstract}

Keywords: language, nation, national language, standard language, Japanese language

\section{Izvleček}

Članek se ukvarja z razmerjem med jezikom in narodom na podlagi zgodovinskega procesa, ki je pripeljal do nastanka modernega japonskega jezika, in predlaga možno razlago narave samih pojavov, kakor sta jezik in narod. Teza članka je, da če razumemo jezik kot objektivno obstoječ, naraven in jasno določen objekt, potem moramo nujno zaključiti, da japonski jezik ni star več kakor sto let.

Ključne besede: jezik, narod, nacionalni jezik, standardni jezik, japonski jezik

\footnotetext{
${ }^{*}$ Luka CULIBERG, Assistant, Department of Asian and African Studies, Faculty of Arts, University of Ljubljana, Ljubljana.

lukaculiberg@hotmail.com
} 


\section{Introduction}

In the 1960s, the crème de la crème of Japanese linguists compiled the famous Heibonsha series of The History of the Japanese Language (Nihongo no rekishi 日 本語の歴史). In its first volume, The Birth of the Language of the Nation ${ }^{1}$ (Minzoku no kotoba no tanjō 民族のことばの誕生), they introduced their linguistic credo with the following words:

As we send into the world this History of the Japanese Language in seven volumes, our wish is to fully grasp the Japanese language as the language of the Japanese nation (nihon minzoku no kotoba). We say again: the Japanese language is nothing else but the language of the Japanese nation (nihon minzoku). Ever since the Japanese nation appeared in its form of unclear origins on these islands, the attempt to understand the history of the Japanese language, which has always developed together with the nation as the language of the nation, is actually in one aspect an attempt to understand the history of the Japanese nation (Kamei, Ōtō and Yamada 2006, 5) (translation mine)

This seminal work on the history of the Japanese language starts by defining its subject as "the language of the Japanese nation." Because the Japanese language is supposed to have existed ever since its dim beginnings somewhere in ancient history, the same must therefore be true of the Japanese nation. ${ }^{2}$ For the purpose of

${ }^{1}$ I translate minzoku no kotoba as "the language of the nation," not to confuse it with the term kokugo 国語, which usually translates as "the national language." Minzoku can alternatively be translated as "ethnicity" but, because the concept of "ethnicity" is no less ideological than the concept of "nation" and because the Japanese nation in the Meiji period was conceived precisely "as an ethnic nation," for which the neologism was coined, minzoku therefore stands for "ethnic nation" in the first place.

${ }^{2}$ A note on the use of the word "nation": while in Japanese there are different terms, such as kokumin or minzoku, which usually translate into English as "nation," sometimes additional adjectives are used for further clarification, such as "political nation" or "ethnic nation" etc. Because the word "nation" in English is rather vague in its meaning and can have various connotations, from "ethnicity" to the nation-state, it needs to be clearly stated that in this paper the word "nation" is used to indicate not its everyday meaning which varies depending on the context or its user's ideological background, but as a "theoretical concept" denoting a clearly defined sociological concept- "a social institution" through which abstracted individuals are integrated into a single community. In the case of Japan the idea of the "nation-state" is built upon the ideological background which presupposes the existence of one single "ethnic" nation, similar to Central European nationalisms, like German or Slovene idea of the "nation." Therefore, when Japanese authors use the word minzoku (or kokumin for that matter), when they refer to "the Japanese nation," they inevitably think about some sort of ethnic group, bound together not only by political participation, but by culture, language and in more radical cases, by blood ties. Thus while English speakers differentiate between "nation" as political notion (like in the case of the United States of America) and "ethnicity" as some sort of "organic" cultural or even racial notion, this paper uses only the former notion to refer to a modern social institution integrating people as "members of the nation," regardless of how this institution is ideologically perceived by 
this paper it should be emphasized that "nation" denotes a specific form of social structure to which people belong as abstract individuals - in itself a phenomenon that is the product of modernity - through a common, a shared identity, as opposed to pre-modern-status based societies, in which people's role and position were inscribed in the social structure by the agency of their birth, status or occupation.

Political leaders and intellectuals have conceived Japanese society as a single "nation" during the second half of the $19^{\text {th }}$ century $^{3}$, and the Japanese language, which functions as the common language used today everywhere in Japan, was formed in that same period. If we follow the argument of Japanese linguists, therefore, we are confronted with the following dilemma: because the Japanese nation is only a hundred and fifty years old, does that mean that the Japanese language is also no older than that? Or, conversely, if the Japanese language is actually older than that, who were the people who spoke it, since the Japanese language, by the above definition, is nothing else but the language of the Japanese nation?

In this paper, I examine the relationship between "language" and "nation" through the historical process by which the modern Japanese language came to exist and I propose some tentative answers as to what this says about the nature of phenomena such as "language" and "nation" themselves. I would like to suggest that if language is understood - as it inevitably is by linguists - as an objectively existing natural and fixed ${ }^{4}$ object, it must indeed be claimed that the Japanese language is no more than a hundred years old.

\section{The Birth of a Language}

What do I mean when I say: "if language is understood as [...]?" In order to understand notions such as "nation" and "language," it is not enough to examine

these same people themselves (i.e. whether they believe they belong to a nation by virtue of citizenship or through some sort of "organic" connection based on the ideology of Blut und Boden).

3 "The Japanese [...] today live a common social life as one 'nation.' However, this is not something that dates back to some very early period. Looked at it in such way, it can be seen that both 'language' and 'nation' have been formed historically, developed together with history; in short, both possess their respective histories." (Matsushima 1956, 2). (translation mine).

${ }^{4}$ Even though linguistics gives much attention to language change and language variation, at the same time it sees languages on a synchronic level as coherent and objectively defined units with names attached to them (English, French, Japanese ...) that are fixed by their material existence in dictionaries and grammar books. Out of this ideological perception about language comes the linguistic belief in "correct" forms as opposed to language "mistakes," language "deterioration" and other anomalies and deviations from its "correct" fixed existence. 
their respective histories, it is also necessary to comprehend the histories of these notions themselves. The concepts themselves have a history through which their meanings change together with the changing reality that they are intended to represent. The word "nation," for example, was a completely new concept that was first translated into the Japanese language sometime during the Meiji period (1868-1912) as a neologism minzoku 民族, which roughly translates as "people of the same kind." The historian Matsushima Eiichi (1956) pointed out to the ambiguity of this term as it is used in the modern language. The term minzoku or nation bears today a meaning that is connected to the circumstances of our presentday society and examples of this meaning are uses such as "national liberation" or "national independence" or "national crisis" etc. However, there are also uses such as "the Yamato nation," a vague expression used alternatively for the Japanese people in the sense of an ethnic group or race (Matsushima 1956, 3). These meanings co-exist and are used interchangeably in an unreflected way, which is a characteristic of ideology.

Similarly, the concept of "language" acquired new meanings when it was appropriated by modern linguistics as a concept inseparable from the concept of "nation," i.e., as a language bearing its "national name" (e.g., the German language, the Dutch language, the Japanese language, etc.). The study of Japanese language is based on the assumption that some "Japanese language" actually exists and has existed since ancient times. The consequence of the assumption that languages possess this unbroken continuity is the ideological view that all actual variations of the language indicate its corruption, decay, and that there are plenty of "mistakes" in the language. The other side of this coin, of course, is the belief that there exists a "correct" language and that language change is something undesirable (Yasuda 2012, 34-35).

Yasuda (2012) points out that the question of what "the Japanese language" is has been on the agenda at least since the $18^{\text {th }}$ century, when scholars of "national learning” (kokugakusha 国学者), such as Motoori Norinaga, raised the issue from a new perspective, although the question first reached beyond narrow scholarly circles in the Meiji Period (1868-1912). Japan in the Meiji Period was suddenly thrown into the world arena of international relationships and, just as has been the case in Europe, language became one of the issues on the agenda. Ever since the appearance of these questions, the Japanese nation and the Japanese language became fixed notions, and objects of academic research "as such fixed notions." 
For example, Ueda Kazutoshi, who studied in Europe and introduced "scientific linguistics" to Japan, claimed that language science means defining the place of language through a comparative method. Comparative linguistics meant reconstructing an older version of a particular language and, through comparison, defining its genetic relationship (Yasuda 2012, 35). Within the context of modern language studies that were dominant at the end of the $19^{\text {th }}$ century and that reinvented the concept of language as a fixed and objective notion, firmly linked to the new concept of nation, many other new notions concerning linguistic practices have appeared. In addition to the concept of "language" itself, notions such as "dialect, standard language, common language" and finally, of course, "national language" came into being, first in scientific and soon afterwards in everyday general discourse.

For example, as a concrete manifestation of the abstract idea of "the Japanese language", the concept of “standard language" or hyojungo 標準語 was introduced at the end of the $19^{\text {th }}$ century. A heated discussion naturally followed as to what this standard language should be and how to construct it. The existence of such a language was imagined as the common language that connects and, at the same time, surpasses all the local variations. However, as Yasuda (2012) wrote, it was not an integrated selection of all the regional dialects that would together constitute a common language, but instead the language of the educated elite of the Yamanote area in Tōkyō was selected as the standard (Yasuda 2012, 38). When the language of Tōkyō was promoted in practice to the status of kokugo 国 語 or the "national language," it was also to be ideologically reinterpreted from being only one "particular" speech to being "the Japanese language" as such. This is not a linguistic problem but an ideological one, though part of its ideological structure is precisely its appearance as a purely linguistic question, and linguists certainly played the most important role in it.

It is possible to conceive the Japanese language as a single, definable language only through a belief that such a language already exists. Based on this belief, actual linguistic variations can then be explained as "dialects" of that imagined language, including the variation that serves as the basis for that language-in the case of Japan, the language of Tōkyō. Definitions of "language" and "dialect," as well as the meaning and value added to them, have therefore nothing to do with some linguistic theory - they are simply the historical result of social processes and their corresponding "language ideologies." For example, Yasuda (2012) 
pointed out that when the standard language was not yet constructed and diffused across the population, dialects were seen as an obstacle and linguists attempted to record dialects in order to "rectify" them. Dialects were understood as a "corruption" of the imagined standard language. However, when the standard finally swept across the whole nation and became an actual linguistic reality, the status of dialects completely changed from being corrupt language variants that needed correction to an expression representing diversity, richness and history of the Japanese language (Yasuda 2012, 40-41).

The process of standardization of the Japanese language at the beginning of the $20^{\text {th }}$ century cannot be equated on a par with the simple "invention" of a language such as Esperanto. The process of standardization of the Japanese language from the late $19^{\text {th }}$ century onward was a process of constructing a new linguistic reality based on existing oral practices and written traditions. Nevertheless, it was still something completely new. Let us briefly look at the historical process that led to the modern linguistic situation.

\section{The History of the Standard Japanese Language}

The development of what we know today as the standard Japanese language, or hyojjungo 標準語, began in the early modern period together with the development of the urban bourgeois society in Edo from the $17^{\text {th }}$ century onwards. With the beginning of the Edo period (1600-1868), and the establishment of the feudal system (bakuhan taisei 幕藩体制) and the spread of commercial networks, both the linguistic map and language awareness began to transform. In that period, a bourgeois or merchant culture started to produce numerous art forms, such as the theatre genre kabuki 歌舞伎 or the puppet theatre ningyō jōruri 人形浄瑠璃, for which artists like Chikamatsu Monzaemon wrote plays depicting the life of Edo, life in the pleasure quarters, love stories and historical dramas of samurai heroes. Then there were prose texts, such as those by Ihara Saikaku, or the yomihon 読本 genre of vernacular literature. These writings were produced by the method of woodblock printing and were thus circulated and spread among a wide audience of the merchant class. In these writings, for the first time the protagonists were commoners, city dwellers, an innovation that represented a major contrast to the nature of previous cultural production, which was completely separated from the common people (Matsushima 1956, 19). 
These texts usually featured extensive dialogues between common people. For the first time, attention turned to the "spoken language" forms of the social groups of the time. What does the notion of "spoken-language" actually mean, though? According to Nomura (2011), in thinking about language there is frequently a discrepancy in the language ideology of linguists and that of the lay people, which is a hindrance in understanding language history (Nomura 2011, 2). When linguists speak of "the history of the Japanese language" or "the history of kokugo," they are usually thinking of the history of the spoken language, although, according to Nomura (2011), these questions usually remain rather vague in their writings. For example, when using classical texts such as The Tale of Genji (Genji monogatari 源氏物語) from the Heian Period as language material, this is of course a "written text" and has to be treated as such, but when linguists reconstruct the Japanese language of the Heian period, they do not usually say whether they are thinking of written or spoken language (Nomura 2011, 4-5). Nomura (2011) divides language into "spoken" and "written" language, and within the written language, he recognizes a "spoken style" and a "written style," the former being the written version of the spoken language, because the language actually spoken is never in fact written down (except perhaps in stenographic reports).

However, if, for most part of the history the written form was a language completely separated from any spoken version existing at a particular time, the aforementioned $17^{\text {th }}, 18^{\text {th }}$ and $19^{\text {th }}$ century popular texts nevertheless introduced contemporary colloquial forms into written language, with perfect awareness of actual linguistic variation, of which they often took advantage specifically for its comic effects. For example, in the text Bathhouse of the Floating World (Ukiyoburo 浮世風呂), a book in the kokkeibon 滑稽本 genre from the beginning of the $19^{\text {th }}$ century, there is a famous dialogue between two women that contrasts the language of the ancient capital of Kyōto and the language of the contemporary political centre-Edo, with all the implications of the social standings or values of certain forms of speech. The two women speak in two different idioms, while having a metalinguistic discussion about which of the idioms is more bizarre or lower in its social standing. The woman from Kyōto makes fun of the other woman's pronunciation. The Edo woman, however, responds by pointing out that it is the Kyōto woman who has ended up living in Edo, the cultural and merchant centre, while the people of Edo feel no need to move anywhere out of their city (Nakamura 1961, 133). Passages like this clearly reflect the transition in prestige from the culture of the ancient capital of Kyōto to the modern bourgeois culture of 
Edo. Eventually, history was on the side of the Edo woman: it was her bizarre idiom - the Edo language - that, less than a hundred years later, became the basis for the standard "Japanese language."

In this sense, "the Japanese language" is therefore the spoken language of the Tōkyō Yamanote area, which was standardized at the beginning of the $20^{\text {th }}$ century. This "language of Tōkyō" first became a subject of discussion in the second half of the Meiji period, when the elementary school system was established as one of the products of the "civilization and enlightenment" movement. Through government-approved textbooks, the general and cultural role that such an education institution plays had a major influence on idioms that had hitherto existed only as regional varieties, and it brought new meanings to the problem of identity connected to the national language (Kuno 1996, 4). However, the idea of something called "the Japanese language" is nevertheless much older than that, and we must also briefly comment on that aspect.

Looking at the notion of "the Japanese language" from the historic perspective, we can see that it was through contact with the "other"- "foreigners"- that the idea of a specific language, proper to Japan, was formed. These ideas can be traced in their embryonic stage to the time of the ancient borrowing of Chinese script and of the language that came with it, although the explicit question relating to the problem of what is the Japanese language was posed by Europeans when they first arrived in Japan, a historical event that created a new context: "What kind of Japanese should be taught to people who don't speak it?"

In the $16^{\text {th }}$ and $17^{\text {th }}$ centuries, when Christian missionaries came to Japan and successfully spread the Christian faith, they produced heaps of texts, grammar books, dictionaries etc. about the Japanese language, which they strove to master for the purpose of proselytization. Looking at those texts, such as the famous Japanese grammar Arte da Lingoa de Iapam by the Jesuit João Rodrigues, we can see that, in those days, foreign missionaries perceived the language of Kyōto, and more specifically, the language spoken by the old aristocracy in Kyōto, to be the "real" Japanese, the so-called "standard" (Tanaka 1996, 32).

A few centuries later, at the end of the feudal era of the Tokugawa bakufu in the middle of the $19^{\text {th }}$ century, James Curtis Hepburn wrote in the preface to the Japanese-English dictionary that he had compiled, that the language of the educated class in Tōkyō is the one that can be understood throughout the country. Three hundred years after the arrival of Portuguese and Spanish missionaries, at 
the beginning of the Meiji period, the proper language that should be taught to foreigners was thus no longer the language of Kyōto but, as we have already seen, the language of the new commercial and political centre - the city of Edo (Tanaka 1996, 37-38).

\section{So, What is the Japanese Language?}

When the question "what is Japanese?" is asked, it is important to realize that the answer is not inherent in the concept of language itself, but rather lies outside of it, in the social circumstances that help shape it. In other words, it is an ideological question. When Tokugawa Ieyasu, the founder of the Tokugawa dynasty, moved into Edo castle on the Kantō plain in Eastern Japan in 1590, Edo was still no more than a small fishing village. After the establishment of the Edo bakufu-the military government of samurai led by the Tokugawa shogun - tens of thousands of Tokugawa vassals and their families from the countries along the Tōkaidō road, such as Suruga and Mikawa, immediately moved into Edo. Merchants from Kyōto and Ōsaka also flocked into the new commercial centre, seeking market opportunities (Tanaka 1996, 38-39). The city thus grew with incredible speed, also attracting more inhabitants from the neighbouring eastern and north-eastern parts of Japan. In a hundred years, the city expanded to a million inhabitants and became a conglomerate of various idioms, giving birth to new ways of speaking, different from the surrounding idioms. Because political power had been transferred to the town of Edo, this new variety of language that was being formed there, gradually gained in prestige.

With the collapse of the feudal system of the Tokugawa bakufu, Japan entered a new era of being an imperial nation state and Edo, the former seat of the bakufu, was renamed Tōkyō and designated the new imperial capital. The language of Tōkyō, perceived as the most prestigious, became the basis for a common language, which, from the end of the $19^{\text {th }}$ century, began to spread through Japan by means of the education system, with the development of new communications, with the help of the press, radio and mass media, as well as the conscript army.

The formation of this new modern language, however, was not so simple. The so-called language of Tōkyō, more specifically of the Yamanote area of Tōkyō, was a spoken idiom, while the new "standard" Japanese language required first and foremost a new "written" form based on the colloquial language. The new 
language was to be formed by a process of converging spoken and written languages. In the post-Restoration years, with attention turning to national unification, the linguistic chaos in Japan became apparent. There were numerous ways in which to write, from kanbun 漢文, yomikudashi 読み下し, sōrōbun 候文 to wabun 和文, which were all very complicated forms used mostly by educated elites. The oldest and most widely respected form of writing was kanbun, the written form in use in Japan up to the $20^{\text {th }}$ century (Clark 2009, 13-14). Kanbun stood for classical Chinese writing, which was in most cases annotated in order to be read in the Japanese way, which was called the kundoku 訓読 method. ${ }^{5}$ This does not mean that it was read in "colloquial Japanese," because no form of standard colloquial Japanese existed, apart from regional, occupational or status based idioms. Rather, as Saitō (2007) points out, through elementary education, the so-called sodoku 素読 style of reading was spread, which meant reciting Confucian classics in a chanting manner, without actually understanding the meaning of the texts (Saitō 2007, 49). The rhythm of sodoku was completely different from everyday spoken language and, by studying it, the children became aware of these differences, identifying the sodoku style specifically as an elevated language in which to narrate things of history or science. So when the rhythm of kundoku reached the wider masses, the split between kanbun and kundoku began, with kundoku gaining independence from kanbun. This type of kundoku written style became the formal written style instead of kanbun, and was the medium in the Meiji period in which imperial edicts or laws were written, as well as the language of education and the media (Saitō 2007, 78). However, this written language was still far removed from any actual colloquial language, and therefore next came the genbun'itchi 言文一致 movement, whose purpose was actually to reform the written language in order for it to correspond to the spoken idiom, which, as we have already seen, was the idiom spoken in Tōkyō. This finally led to the birth of the standard Japanese language, a codified language that is ideally written down as well as spoken on public occasions and in the media.

\footnotetext{
${ }^{5}$ None of the mentioned styles was really standardized and, as Clark (2009) pointed out, there was little uniformity in the various writing styles. Authors sometimes used slightly different forms of the language even in the same passage. Within kanbun itself, variant forms can therefore be distinguished, such as jun kanbun (pure Chinese text), kanbun kundoku (Chinese text with explanation reading), kanbun chokuyakutai (literal translation of Chinese text) or kanbun kakikudashibun (a Chinese writing reordered to Japanese syntax) (Clark 2009, 14-15). Besides kanbun (classical Chinese text) there were other literary styles, for example the so-called classical Japanese text (wabun) as well as other hybrid forms, such as sōrōbun (epistolary style) or wakan konkōbun (mixed Japanese-Chinese style).
} 


\section{Conclusion}

Such, in short, is the history of the modern Japanese language. The concept was not the result of a new "scientific linguistics" that would theoretically construct it, as Ueda Kazutoshi and other modern linguists might have thought, but was closely tied to the ideology of a single nation. Being an ideological concept in itself, defining language has proven to be full of difficulties, arguments, contradictions etc. For example, based on the belief that there exists a single "Japanese language" as an objectively definable object, the actual variation of linguistic practices among the population may be defined as "dialects." Consequently, from the point of view of dialectology, actual Japanese, its true condition, is nothing but the sum of various dialects. The idiom spoken in Kyōto is "the Kyōto dialect," the variety spoken in Kagoshima is "the Kagoshima dialect" and the idiom spoken in Tōkyō is, technically speaking, simply "the Tōkyō dialect." Based on this understanding, there is a belief among certain linguists that standard language doesn't actually exist in Japan. There certainly exists a common language, understood throughout Japan, but the most desirable form of Japanese, one that could be termed the "standard language," does not exist (Kuno 1996, 8). Complete satisfaction with what is considered to be "standard" language can therefore never really be achieved.

Precisely because language is an ideological notion, the ideal form that ideology presupposes can never be achieved. The common language used in Japan today is unable to live up to its ideological demands and, consequently, both language ideologues and the language-conscious general populace are in a permanent state of dissatisfaction. As a result, the prevailing stance towards the state of the language is expressed through lamentations about Japanese being "all mixed up," "in decay," "deteriorating," while "the young generations can no longer speak it properly" etc. The ideological belief that a certain linguistic unity (e.g., "the Japanese language") possesses an unbroken continuity over centuries gives birth to the notion that real and observable linguistic variety reflects "corruption" of, or "mistakes" in the language.

Language, as seen from the ideology of a single nation, is a basic constituent that defines a particular national group. In the modern era, language started to give unity to groups that had surpassed small regional societies and it began to set its outer borders. A variety of idioms with no specific names or borders came to be called a certain name, its orthography defined, its borders drawn and it became 
established as a "national language" with the help of a circular definition: defining "Japanese people" was made possible by describing them as "the people who speak the Japanese language." The Japanese language, conversely, was defined as "the language spoken by the Japanese people."

It is not possible to define a certain language from within that language itself, but only indirectly through the medium of "nation" or state. That is why the ultimate problem of linguistics remains the question of a definition of a particular language; in other words, how to consider languages as clearly defined linguistic units.

One of the major tasks in modern Japan was the attempt to unify the regional and status differences in language, as well as the differences between the written and the spoken language. The concept of the "national language" was an ideological mechanism that enabled such unification, by providing both the unity on a synchronic level and the illusion of history on a diachronic level. In the end, it is "the Japanese language" that constructed the Japanese nation, and it is "the Japanese nation" that established the modern Japanese language.

\section{References}

Clark, Paul H. 2009. The kokugo Revolution: Education, Identity, and Language Policy in Imperial Japan. Berkeley: Institute of East Asian Studies, University of California.

Kamei, Takashi 亀井孝, Ōtō, Tokihiko 大藤時彦, and Yamada, Toshio 山田俊雄. 2006. Nihongo no rekishi 1. Minzoku no kotoba no tanjō日本語の歴史 1 民族のことば の誕生 (The History of the Japanese Language 1: The Birth of the Language of the Nation). Tōkyō: Heibonsha.

Kuno, Mariko 久野マリ子. 1996. “Hajimeni” はじめに (“Introduction”). In Tōkyōgo no yukue. Edogo kara tōkyōgo, tōkyōgo kara sutandādo nihongo e 東京語のゆくえ 江 戸語から東京語、東京語からスタンダードへ (Towards the Tokyo Language: From Edo Language to Tokyo Language, From Tokyo Language to Standard Language), edited by Kokugakuin daigaku, Nihon bunka kenkyūjo, 1-19. Tōkyō: Tōkyōdō Shuppan.

Matsushima, Eiichi 松島栄一. 1956. “Minzoku to kotoba”民族とことば ("Nation and language”). In Kōza nihongo 1. Minzoku to kotoba 講座日本語 1 民族とことば (Lectures on Japanese 1: Nation and Language), edited by Ōshima Yoshio 大島義夫, 1-21. Tōkyō: Ōtsuki shoten. 
Nakamura, Michio 中村通夫, ed. 1961. Nihon koten bungaku taikei 63. Ukiyoburo 日本古 典文学体系63 浮世風呂 (Compendium of Classical Japanese Literature 63: Bathhouse of the Floating World). Tōkyō: Iwanami shoten.

Nomura, Takashi 野村剛史. 2011. Hanashikotoba no nihonshi 話し言葉の日本史 (Japanese History of the Spoken Language). Tōkyō: Yoshikawa kōbunkan.

Saitō, Mareshi 齋藤希史. 2007. Kanbunmyaku to kindai nihon. Mō hitotsu no kotoba no sekai 漢文脈と近代日本もう一つのことばの世界 (The Context of kanbun and the Modern Japan: The World of Another Language). Tōkyō: NHK.

Tanaka, Akio 田中章夫. 1996. “Tōkyōgo to hyōjungo” 東京語と標準語 (“Tōkyō Language and Standard Language"). In Tōkyōgo no yukue. Edogo kara tōkyōgo, tōkyōgo kara sutandādo nihongo $e$ 東京語のゆくえ 江戸語から東京語、東京語 からスタンダードへ (Towards the Tokyo Language: From Edo Language to Tokyo Language, From Tokyo Language to Standard Language), edited by Kokugakuin daigaku, Nihon bunka kenkyūjo, 21-76. Tōkyō: Tōkyōdō Shuppan.

Yasuda, Toshiaki 安田敏朗. 2012. Nihongogaku no manazashi 日本語学のまなざし(A Look on the Studies of Japanese Language). Tōkyō: Sangensha. 